\title{
MULTI-SIDED PLATFORMS: CURRENT STATE AND FUTURE RESEARCH
}

\author{
S.A. YABLONSKY
}

Graduate School of Management, St. Petersburg State University, Russia

In the digital age traditional ways of doing business have been transformed by a group of new platform-driven companies like Facebook, Amazon, Uber, Airbnb and some others. This relatively new digital economy research phenomenon requires inclusive understanding. The paper explores and questions platform research in the context of digital MSPs. It provides main definitions and discusses the concept of digital platform stack framework. The characteristics, advantages and disadvantages, opportunities and threats associated with the activities of digital platforms have been considered. The paper systematizes current research with a focus on the platform digital transformation, strategy, business models and architecture and suggests agenda for future research.

Keywords: business platform, technology platform, multi-sided platform, platform business model, platform stack.

JEL: O31, O32.

\section{INTRODUCTION}

Over recent decade there has been a rapid global transition from industrial to digital economy [Judah, 2016]. Digital transformation (DT) and resultant business model innovation have fundamentally altered consumers' expectations and behaviors, pressured traditional firms and disrupted numerous markets. DT of enterprises across industries is an emerging phenomenon. At a high level, DT covers the intense chang- es taking place in society and industries through the use of digital technologies [Vial, 2019]. At the organizational level, it has been contended that firms must find means to innovate with new technologies by creating "strategies that embrace the implications of digital transformation and drive better operational performance" [Hess et al., 2016, p.123]. Implementation of the DT strategy as well as chang0es to an organization, including its structure, processes and culture, requires bringing in

Postal Address: St.Petersburg State University, Graduate School of Management, 3, Volkhovskiy per., St. Petersburg, 199004, Russia.

(C) S.A. Yablonsky, 2019

https://doi.org/10.21638/spbu18.2019.407 
the capability to generate new paths for value creation [Vial, 2019]. Transformation processes involve technologies, firms' capabilities and interrelationships between the technology providers and recipients. The process also needs efforts and resources to demote the business, organizational, cultural and market boundaries. Thus, platform DT related with platform intermediaries constantly take charge of bridging this kind of communication gaps [Yablonsky, 2016b].

Now platforms have become an important economic force with a total market value of $\$ 4.3 \mathrm{trl}$ and an employment base of at least $1.3 \mathrm{mln}$ direct employees and millions of others indirectly employed [Evans, Gawer, 2016]. The regional surveys [Evans, 2016; David-West, Evans, 2016] identify 62 major platform companies operating across Asia with a market capitalization of $\$ 800 \mathrm{mln}$ or more and 42 platform companies operating in 33 African countries. The market value of the 62 Asian companies now exceeds $\$ 1.1 \mathrm{trl}$ and has a powerful growing influence on shaping markets throughout the region and worldwide. Platforms are increasingly prevalent: 16 of the 25 most valuable brands for 2014 function as platforms [Taube, 2014]. P. Evans and A. Gawer stated that platform businesses can be found in a growing number of industries including social networking (Facebook, LinkedIn); Internet auctions and retail (Amazon, eBay, Angie's List); online financial and human resource functions (Workday, Elance-oDesk, Freelancer, WorkFusion), urban transportation (Uber, Lyft, Sidecar), mobile payment (Mahala, Square) and clean energy (Sungevity, SolarCity, EnerNOC) [Evans, Gawer, 2016]. Airbnb or Uber threaten to disrupt wellestablished industries like taxi or hospitality services using platform-driven business model. It is stated that platforms facilitate generation of a potentially very large number of complementary innovations by tapping into the innovative capabilities of many external economic agents (actors) and function as a technological foundation at the heart of innovative business ecosystems [Tiwana,
2014; Jacobides et al., 2018]. P. Evans and A. Gawer have shown that platform companies are now visible global phenomena: they operate not only in advanced industrial markets, but throughout the entire world thanks to the growing availability of mobile digital technologies and Internet [Evans, Gawer, 2016].

M. Cusumano, A. Gawer and D. Yoffie divide all platforms into three types [Cusumano, Gawer, Yoffie, 2019]:

1. innovation platforms enable third-party firms to add complementary products and services to a core product or technology (examples: Google Android, Apple iPhone operating systems or Amazon Web Services);

2. transaction platforms enable the exchange of information, goods, or services (examples: Amazon Marketplace, Airbnb, or Uber);

3. hybrid platforms (emerging type).

They prove that five of the six most valuable firms in the world are built around these types of platforms [Cusumano, Gawer, Yoffie, 2019]. In their analysis of data going back 20 years, they identify 43 publicly-listed platform companies in the Forbes Global 2000. Authors assert that "these platforms generated the same level of annual revenues (about $\$ 4.5$ billion) as their non-platform counterparts, but used half the number of employees. They also had twice the operating profits and much higher market values and growth rates" [Cusumano, Gawer, Yoffie, 2019].

In order to provide managerial guidance for platform DT, research needs to enhance understanding of how firms can achieve a sustainable competitive advantage by building on specific platform resources, which strategies they should adopt to win, and how the firm's internal organization structure must change to support these strategies [Verhoef et al., 2019].

This paper contributes to existing discussions on platform DT, strategy, business models and architecture by taking a multidisciplinary focus. We outline existing views 
on digital platform transformation from the industrial organization (IO) economics, technology management and strategic management perspectives. Using this review as a basis, we propose a future research agenda in the multiple domains that focuses on the influence of technological innovations on the emergence of the platforms.

Our review of the economic literature and the evidence on the progress of platforms provides considerations on the themes and directions of research. Such work can help policy makers and businesses to foster better understanding of digital platform development in developed and emerging markets.

The paper is organized as follows: first, we introduce main platform DT defenitions and the platform conceptual framework, the methodology for which is explained in the following section; next, we discuss the main findings of platform research; finally, we propose an agenda for future research and conclude our findings.

\section{DEFINING DIGITAL PLATFORMS}

Multi-sided platforms have existed for years. For example, offline malls link consumers and merchants, paper newspapers connect subscribers and advertisers. For several decades, scholars have discussed platform concepts from a non-digital worldview. The fundamental insight that there is a broad class of businesses of this sort that have economic features not well explained by standard textbooks was presented by [Rochet, Tirole, 2003]. Scholars have studied market power in two-sided markets since the 1980s [Rochet, Tirole, 2003; 2004; 2006]. A. Gawer and M. Cusumano investigated how companies could compete through platforms [Gawer, Cusumano, 2008]. J. Moore and coauthors proposed strategic shift from competition towards coopetition around a shared niche [Moore et al., 1997]. Recent books [Tiwana, 2014; Evans, Schmalensee, 2016; Parker et al., 2016] specify how platforms are shaping business and business models and actually are transforming entire economies. Platform research is generally formalised both within the industrial innovation management literature [Gawer, 2014; Thomas, Autio, Gann, 2014] and the economics literature [Parker, Van Alstyne, 2005]. The MPS literature is now regularly cited by competition authorities and courts [Evans, Schmalensee, 2018]. These businesses pose novel problems for competition policy [Evans, 2003; Evans, Schmalensee, 2016; 2018].

Platforms can take a variety of forms. There are many ways to categorize them. One typology of platforms is proposed by P. Evans and A. Gawer (Fig. 1).

Another classification is based on the structure of platform ecosystem and control. All platforms represent ecosystem with the same basic structure, comprising the following types of economic agents roles [Parker, Van Alstyne, 2014; Van Alstyne, Parker, Choudary, 2016]:

1) owners of platforms or platform sponsors control their intellectual property and governance. The owner sets the direction, controls the underlying platform technology and provides the overall organizing structure for the platform via rules, governance and ecosystem support. It can facilitate the ecosystem work by helping participants see how they are better off by being part of the system rather than outside of it. This role can be performed by one or many firms in alliances what is typical for sharing or collaborative economy [Como et al., 2016];

2) platform providers operate as a platforms' interface with users. The platform provider defines common components, rules and architecture for the users of the platform. This role can be done by one or many firms;

3) users (supply side) or producers create their offerings. These are content and application developers. Producers provide specific items that attract users to the platform - music, videogames, information, services, etc.; 


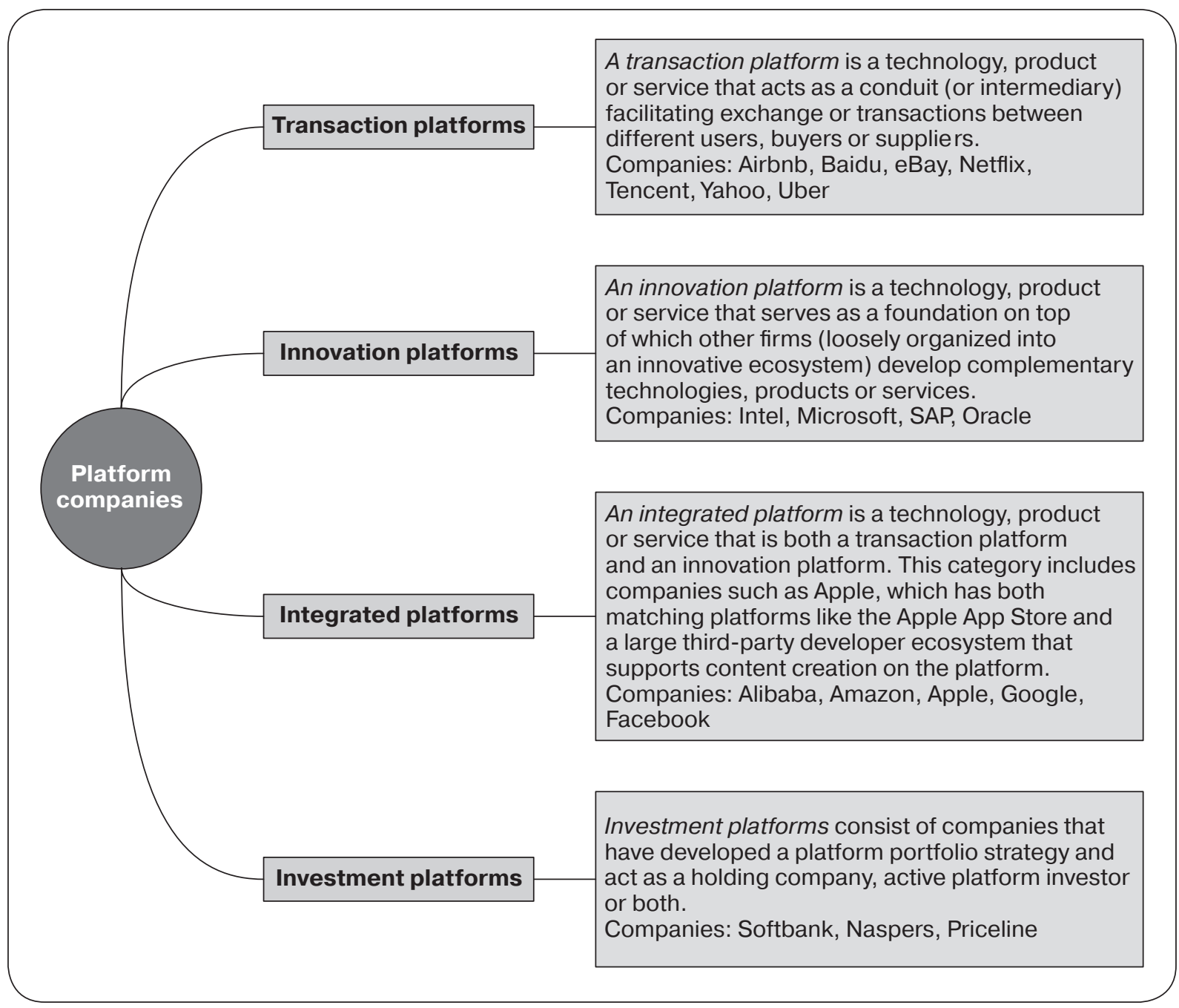

Based o n: [Evans, Gawer, 2016].

Fig. 1. Platform typology

4) users (demand side) or the target consumers of the platform solutions and services use producers' offerings. They can be individuals or organizations.

A. White showed that large body of empirical work examines substances including [White, 2018]:

- regulation of online privacy (e.g. [Goldfarb, Tucker, 2011]);

- contexts in which users substitute between online and offline platforms (e.g. [Goldfarb, Tucker, 2011]) and the effect of such substitution on broader social trends (e.g. [Gentzkow, Shapiro, 2011]);
- the dynamics of social behaviour in large online communities (e.g. [Zhang, Zhu, 2011]) and the ways in which online sellers experiment (e.g. [Einav et al., 2011; Levin, 2012]).

Most of today's platforms are principally digital (or online) [White, 2018; Menon et al., 2018]. They capture, transmit and monetize data, including personal data, over the Internet and other networks [Evans, Gawer, 2016]. They may not be purely digital, but most successful digital platforms currently take advantage of the digital innovations and power of pervasive Internet 
connectivity in the hand of millions of users. Platform technologies are essential for coordinating suppliers and buyers to deliver consumer value. Facebook is a type of platform that coordinates suppliers and consumers of social information. Without a social media platform such as Facebook, it would be much more difficult and costly for people to exchange social information. Although concepts and notions can be borrowed from these streams of platform literature, digital platforms are particularly different in numerous ways [White, 2018; Yablonsky, 2018a; 2018b]. A platform provides common standards, interfaces and tools to power core technologies in order to increase the productivity and profitability of a company, a set of companies or users [Teece, 2010].

A successful MSP usually creates a network of the relationships among economic entities (producers, stakeholders, distributors, consumers, government agencies, etc.) that, through competition and/or cooperation, facilitate the creation and distribution of a platform product or service. The platform ecosystem metaphor could be used to describe such platform network that is characterized by open, flexible, demand-driven, interactive networked architecture and collaborative environments [Gawer, Cusumano, 2014]. The ecosystem concept is of increasing significance in the field of the enterprise management, system design and business architecture. Starting from Moore's work [Moore, 1996], the ecosystem concept has been actively discussed in management studies. The coevolution of the ecosystem is typically reliant on the technological leadership of one or two firms that provide a platform around, which other system members that provide inputs and complementary goods align their investments and strategies with [Parker, Van Alstyne, Jiang, 2017]. For some social and crowdfunding digital platforms creation of the digital ecosystem is a critical success factor for positive platform dynamics.

The operating models and capabilities of the generation of "born digital" platform organizations founded after 1995 are based on exploiting digital technologies and technological platforms as a core competency. They are:

- not just startups (Amazon and eBay are 25 years old);

- not just small (Google has about 100000 employees);

- not just pure digital businesses (Tesla Motors makes cars);

- not just American (Alibaba Group is Chinese, Yandex and Mail.ru Group are Russian).

Digital platform strategy becomes extremely complex as firms consider dynamic interactions of a multilayered business ecosystem [Teece, 2012]. The concept of platform innovation can be widely defined as architecting new platform strategies and business models (or BM), making and promoting new platform products and services, developing new platform processes to facilitate platform activities, to interact with platform actors and to design new platform structures for industry institutions [Leiblein, 2015; Yablonsky, 2018a; 2018b]. For example, today simplified Amazon platform business model portfolio consists of $10+$ different business models, including Amazon digital market place, Amazon Web Services (AWS) - Cloud Computing Services, Amazon Fire TV and others.

Unlike a traditional business, with clear internal and external structures, a platform provides business with a foundation where resources can come together in different combinations in order to create value. Some resources may be inside, permanently owned by the platform; some may be shared; and some can come from an outside ecosystem. The value comes largely from dynamic connection of those resources, different actors and network effects between them. The platforms exponentially grow creating large systems of information technologies, businesses and people [De Reuver, Sørensen, Basole, 2018]. Platform providers such as Google, Facebook, Amazon, Alibaba and eBay are transforming the Internet into de facto closed domains, implying that all relevant 
interactions take place outside the view of researchers [Eaton et al., 2015].

There is a rising interest in multi-sided platforms (MSPs) in the scholarly literature [McIntyre, Srinivasan, 2017]. Digital technological platforms are altering phenomena over the entire IS domain [De Reuver, Sørensen, Basole, 2018]. Architectures of platform artefacts are changing as the modularity of digital platforms is replacing traditional monolithic approaches [Tiwana, Konsynski, Bush, 2010]. As digital platforms are competing on multiple levels of the technical and business architecture, specifying the appropriate unit of analysis is becoming increasingly difficult [Yablonsky, 2018 a; 2018b]. To architect a digital platform-based business, organizations must lead their business to take a business driven, outside-in approach.

The enterprise architecture (EA) framework is a set of assumptions, concepts, values and practices that establishes a way of looking at enterprise via views on architectural models [Bente, Bombosch, Shailendra, 2012]. EA relates to the practice of business optimization that addresses business architecture, performance management, organizational structure and process architecture. It consists of describing the current and future structure and behavior of an organization's processes, information systems, personnel and organizational business units so they align with the organization's strategic direction, going beyond information technology. At the same time Industry 4.0 that refers to the combination of several major innovations in digital technology that are hovered to transform the energy and manufacturing sectors and the industrial Internet of Things (IoT) enable powerful new ways of organizing global operations, platform business model design and innovative multilayered EA. Today, there exist a number of EA frameworks with the goal of addressing the basic challenge of assessing, aligning and organizing business objectives with technical requirements and strategies. Examples include the Zachman Enterprise
Framework, The Open Group Architecture Framework, OMB Federal Enterprise Architecture and The Gartner Methodology [Bente, Bombosch, Shailendra, 2012]. Before enterprise can configure, build or restructure a platform using such EA frameworks, it must put down comprehensive plan to ensure that the essential BM portfolio, platform capabilities and resources are present, technologies are both compatible and useful and the proper infrastructure is in place to support the EA framework [Bente, Bombosch, Shailendra, 2012].

Drawing on existing knowledge in the field of platform BM patterns [Osterwalder, Pigneur, 2010; Osterwalder et al., 2014; Blosch, Burton, 2016; Blaschke et al., 2017a; 2017b] and platform research [Evans, Gawer, 2016], we argue that a metastructuring perspective serving through the platform landscape represents an important contribution that remains missing. The objective of recent research was to create such a metastructuring perspective using a taxonomyenabled methodology to create a consistent structure of the digital platform innovation framework [Yablonsky, 2018a; 2018b]. The paper [Yablonsky, 2018a] introduces the topdown approach of platform EA in the context concept of choosing platform BM, architecture, capabilities and the obstacles that lie in the way of platform configuration, with the objective of providing a better alignment between business and IT. MSP is usually formed by a platform architecture with a subset of components (hardware, software, services), rules (technical standards, protocols for information exchange, policies and contracts that govern transactions) and a strategy with portfolio of BMs employed by users in most of their transactions. For example, the search MSP building blocks are shown in Fig. 2. As can be seen it has minimum three sides: content providers (who need users), users/searchers (who search for content) and advertisers (who want access to users).

Definitions of core concepts on digital platforms are placed in Table 1 . 


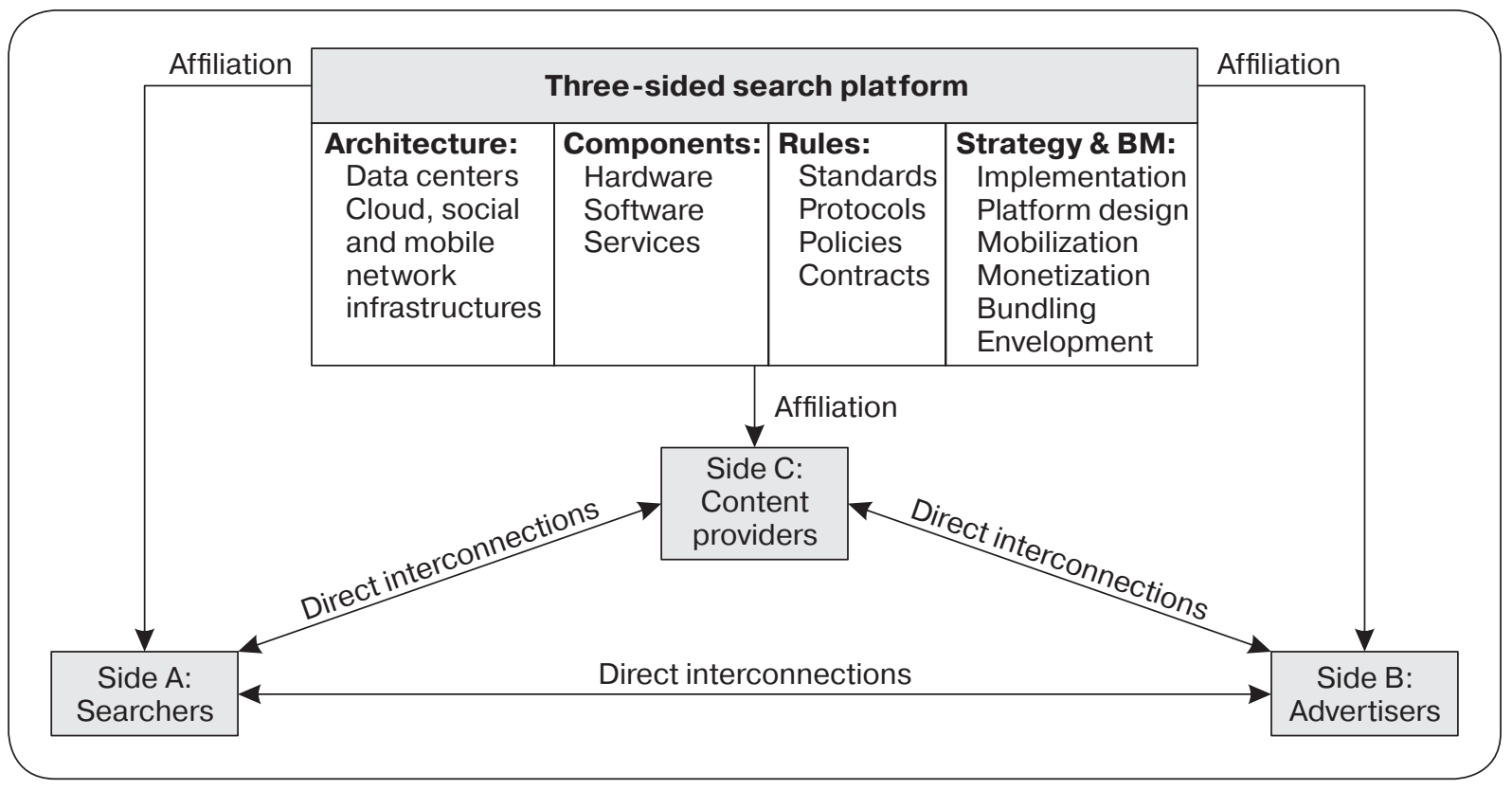

B a s ed on: [Yablonsky, 2013; 2016a].

Table 1

Definitions of core concepts on business platforms

\begin{tabular}{|c|c|}
\hline Concept & Definition \\
\hline 1 & 2 \\
\hline $\begin{array}{l}\text { Multi-sided platform } \\
\text { (organizational view) }\end{array}$ & $\begin{array}{l}\text { Multi-sided platform is an organization that creates value primarily by enabling } \\
\text { direct interactions between two (or more) distinct types of affiliated customers } \\
\text { [Hagiu, Wright, 2015]. MSP mediates different groups of users, such as buyers } \\
\text { and sellers. MSPs reduce transactions costs and thereby facilitate value-creating } \\
\text { interactions between two or more different types of economic agents [Evans, } \\
\text { Schmalensee, 2018]. D. S. Evans and R. Schmalensee argued that: } \\
\text { - MSPs are most often created and operated by private for-profit firms. Apple's } \\
\text { iPhone operating system, for instance, is a two-sided platform linking app de- } \\
\text { velopers and consumers; } \\
\text { - some MSPs have been the products of non-profit entities (Visa and MasterCard, } \\
\text { for instance, were effectively nonprofit cooperatives for many years); } \\
\text { - few MSPs have been created by governments (this describes national currencies). } \\
\text { pays play critical roles in many economically important industries including } \\
\text { operating systems and various internet-based industries such as online market- } \\
\text { places and ride-sharing apps [Evans, Schmalensee, 2018] }\end{array}$ \\
\hline Multi-sided markets & $\begin{array}{l}\text { According to the definition of previous studies [Evans, Hagiu, Schmalensee, } \\
\text { 2006; Hagiu, Wright, 2015; Evans, Schmalensee, 2018], a multi-sided market } \\
\text { exists, when at any point in time, there are: } \\
\text { - two or more distinct groups of customers; } \\
\text { - the value obtained by one kind of customers increases with the number } \\
\text { of the other kind of customers; and an intermediary is necessary for internal- } \\
\text { izing the externalities created by one group for the other group }\end{array}$ \\
\hline
\end{tabular}


Table 1 (continued)

\begin{tabular}{c|l}
\hline $\mathbf{1}$ & $\mathbf{2}$ \\
\hline Technology platform & Technology platform is defined as building blocks that act as a foundation upon
\end{tabular}
which an array of firms (a business ecosystem) develop complementary products, technologies or services [Gawer, 2009], implying the following requirements for a platform:

- it should perform a critical function of the overall system or should solve a crucial technological issue of an industry;

- it should be easy to connect to "build upon" and provide space for new and unplanned usage.

There are two main groups of technological platforms: product/service platforms and network platforms

Network technological platform A network technological platform or network platform is usually based on digital network(s) building blocks [Hagiu, Wright, 2015]. Network platforms differ from product platforms because of stronger network effects, switching costs and multi-homing costs

Main platform economic agents (actors) Multi-sided platform ecosystem

Customers, Partners, Emploees, Smart things/Smart machines

Platform ecosystem contains a number of firms and other institutions that work together to create and sustain new markets and new products [Teece, 2012].

An ecosystem may be anchored by a MSP. The co-evolution of the ecosystem is typically reliant on the technological leadership of one or two firms that provide a platform around, which other system members that provide inputs and complementary goods align their investments and strategies with

\begin{tabular}{l|l}
\hline Ecosystem & Crganizational view)
\end{tabular}
\begin{tabular}{l|l}
\hline Ecosystem & A collection of complements (apps) to the core technical platform, mostly
\end{tabular} (technical view) supplied by third party

Network externalities A MSP creates value by coordinating the multiple groups of agents and, (effects)

in particular, ensuring that there are enough agents of each type to make participation worthwhile for all types [Evans, Schmalensee, 2018].

The value of the platform depends on the number of users in the same user group. That is called direct network externalities or effects.

In many cases, greater involvement by economic agents of at least one type increases the value of the platform to agents of other types. Such indirect network effect (externality) function something like economies of scale on the demand side, tending to make larger platforms more attractive to potential customers [Evans, Schmalensee, 2018]

MSPs in the context $\quad$ MSPs in the context of digital business exist at many levels. They range from highof digital business level platforms that enable a platform business model to low-level platforms that provide a collection of business and/or technology capabilities that other products or services consume to deliver their own business capabilities. Platforms that enable a platform business model have associated business ecosystems. They typically expose their capabilities to members of those ecosystems via APIs. Internal platforms also expose their capabilities via APIs. But they may offer other mechanisms, such as direct data access, as required by the products that consume them

\begin{tabular}{l|l}
\hline Applications (apps) & $\begin{array}{l}\text { Executable pieces of software that are offered as apps, services or systems } \\
\text { to end-users }\end{array}$ \\
\hline Boundary resources & $\begin{array}{l}\text { Software tools and regulations facilitating the arms' length relationships between } \\
\text { the involved parties }\end{array}$ \\
\hline
\end{tabular}


Table 1 (end)

\begin{tabular}{l|l}
\hline \multicolumn{1}{c|}{$\mathbf{1}$} & \multicolumn{1}{c}{$\mathbf{2}$} \\
\hline Platform openness & The extent to which platform boundary resources support complements \\
\hline $\begin{array}{l}\text { Digital MSP disrup- } \\
\text { tion }\end{array}$ & $\begin{array}{l}\text { It is a process of changing multi-sided markets through digital capabilities, } \\
\text { channels and assets. Digital business innovation forms disruptive platform effects }\end{array}$ \\
\hline
\end{tabular}

\section{FRAMEWORK FOR SYSTEMATIC PLATFORM INNOVATION AND MANAGEMENT}

While studying digital platforms is already challenging as a consequence of their distributed nature [Constantinides, Henfridsson, Parker, 2018], developments in the business environment pose even larger research challenges for researchers. To manage digital platform business model (BM) portfolios and multilayered platform business ecosystems, companies are creating a digital platform stack to share critical assets. The variance in company's digital business performance is a function of differences in the platform resources and capabilities of competing companies.A digital platform is a business-driven framework that allows a community of partners, providers and customers to share and enhance digital processes and capabilities or to extend them for mutual benefit [Burton, Basiliere, 2016]. This framework allows different combinations of BMs, leadership, talent, delivery and IT infrastructure platforms that power digital business ecosystems. There has been a growing interest in utilizing more than one methodology and method possibly from different spheres of thought within the same intrusion of digital economy and digital platforms. R. Flood and M.Jackson mentioned that enormously complex, multidimensional and illstructured problems that comprise social, behavioral, coercive, exploitative and manipulative components require such combinations and perennially preoccupied contemporary systems thinkers to develop different and independent endeavours and competing orientations [Flood, Jackson, 1991]. Authors propose a theoretically and practically improved version of Total Systems Intervention as a sophisticated alternative, in a far more detailed and penetrating manner and assess its flexibility, responsiveness and sustainability in multi-methodology interventions.

In digital platform business, business and technology are complicated. To model a digital business, managers must understand what is needed for a business to achieve its goals and how these goals translate into actionable strategy. A digital platform business requires much more than technology (e.g. leadership, talent, skills and new BMs). A digital MSP is a businessdriven framework that allows a community of partners, providers and customers to share and enhance digital processes and capabilities or to extend them for mutual benefit [Burton, Basiliere, 2016]. This framework allows different combinations of BMs, leadership, talent, delivery and IT infrastructure platforms that power digital business ecosystems. A. Osterwalder defined a $\mathrm{BM}$ as "a conceptual tool that contains a set of elements and their relationships and allows expressing the business logic of a specific firm [Osterwalder, 2004]. It is a description of the value a company offers to one or several segments of customers and the architecture of the firm and its network of partners for creating, marketing and delivering this value and relationship capital, to generate profitable and sustainable revenue stream". BM is a useful lens for understanding a company's fundamental value creation logic. Currently, the interpretation of BMs as formal conceptual representations/descriptions becomes predominate [Osterwalder, 2004; Gassmann, Frankenberger, Csik, 2014]. A. Osterwalder and I. Pigneur have developed the popular 


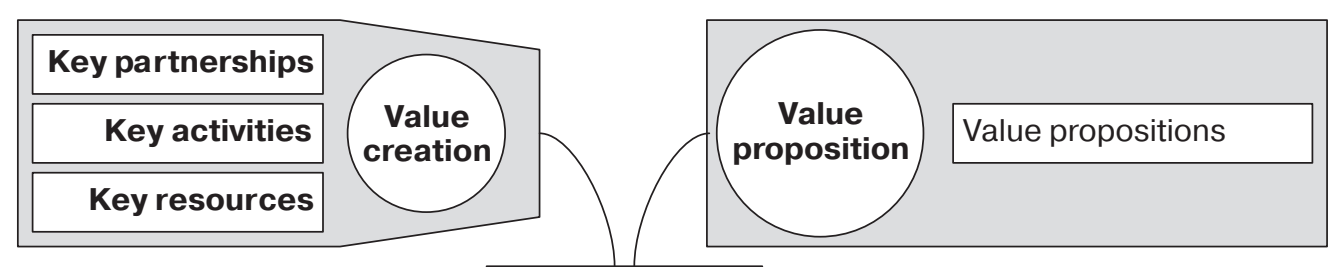

Business model

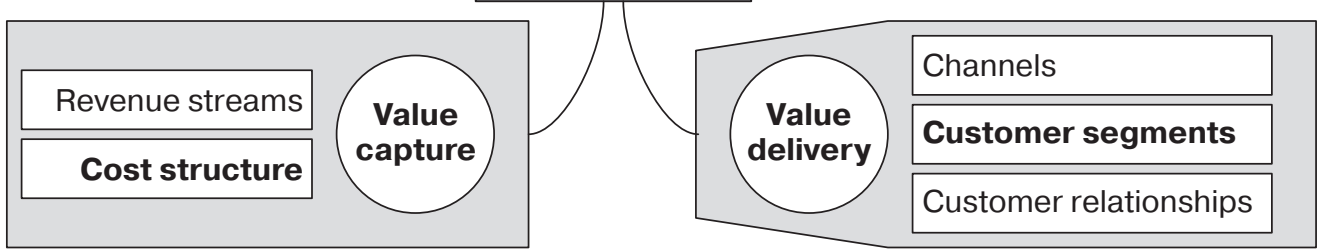

Fig. 3. Business model building blocks with meta-components

B as ed o n: [Günzel, Holm, 2013; Gassmann, Frankenberger, Csik, 2014].

Business Model Canvas, taxonomy of nine main BM building blocks [Osterwalder, Pigneur, 2010] (Fig. 3).

We use Business Model Pattern (BMP) concept developed by [Osterwalder, Pigneur, 2010; Gassmann, Frankenberger, Csik, 2014; Remane et al., 2017; Yablonsky, 2018a; 2018b] as a way of structuring platform digital value drivers and platform BMP. We provide MSP BMP as a basic conceptual framework and knowledge management tool for describing, analysing and interpreting non-price instruments used by digital platforms, especially platform intermediaries. Using the MSP BMP as the basis of the digital intermediaries' analysis and decision making, we update this pattern for each industry. A platform BM is a useful lens for understanding the company's platform underlying logic because it explains what value is provided, how this value is created and delivered and how profits can be generated therefrom.

This concept helps to understand the capturing value from technological innovations and platforms [Chesbrough, Rosenbloom, 2002; Osterwalder, Pigneur, 2010; Osterwalder et al., 2014], the boundaries of a firm [Zott, Amit, Massa, 2010], and create a direct connection between business strategy and business processes [Al-Debei, Avison, 2010]. Therefore, we replace basic platform dimensions with platform BM pattern dimensions based on platform expanded results of previous studies [Remane et al., 2017; Yablonsky, 2018b] (Appendix 1).

Recent platform research initially looks for constructing the conceptual foundations and requirements of an appropriate multimethodology digital platform approach. It aims for a multidimensional multilayered business platform framework development in order to facilitate understanding, analysis and structure of business and digital platform integration for enterprises and industries. This approach proved particularly beneficial for the field due to the current lack of systematic empirical analysis from digital platform management research. The development is guided by the approach of Nickerson, Upkar and Muntermann [Nickerson, Upkar, Muntermann, 2013] and foresight methodology [Thom, 2010], which facilitates the iterative combination of conceptual-to-empirical and empirical-to-conceptual approaches.

Following key dimensions of platform framework are selected [Yablonsky, 2018b]: 1) basic platform dimensions (components, rules strategies); 
2) additional platform players or economic agents or sides dimensions (producers, consumers, providers, owners);

3) innovation technology dimensions (innovative dynamic digital key elements).

Dimensions of platform frameworks have become popular to describe the convergence of innovation technologies [LeHong et al., 2016; LeHong, 2019]. In particular, we refer to different approachers with different stage of granularity: from simplified four dimensions (social, mobile, analytics, cloud and IoT to SAP Digital Key Elements from BMDI: SAP Business Model Innovation Methodology [Oswald, Kleinemeier, 2017], IDC Innovation Accelerators and third-platform concept [IDC, 2017] and dynamic Gartner Top 10 Strategic Technology Trends 20182020. For example, innovation technology dimensions may include cloud computing, mobile technologies, Big Data, IoT, Artificial Intelligence and other.

Every firm has tangible and intangible business assets (processes, human talent, technologies, infrastructure and information) that can be used or developed to bring the digital business platform to life [Burton, Basiliere, 2016]. As it was mentioned [Yablonsky, 2018a; 2018b], multi-sided business platform is usually a subset of components (hardware, software, services), rules (technical standards, protocols for information exchange, policies and contracts that govern transactions) and strategy/BMs building blocks employed by users in most of their transactions. R. Hunter and M. Coleman stated that "in the context of digital business, a platform is an architecturally innovative means of sharing assets such as algorithms, data and functions with ecosystems of people, businesses and things. A platform typically includes tools, functions and support for multiple customer segments (e.g., buyers and sellers; students, faculty and administrators)" [Hunter, Coleman, 2016]. With new digital BMs, resources may be added or combined in new and different ways to support the digital platform strategy or an organization may start with a set of resources applied across the entire business or apply specific assets in a few areas.

The business and technology platform stacks constitute digital platform stack [Yablonsky, 2018a; 2018b] (Fig.4, Appendix 2). Business platform stack includes BM and leadership platform, talent platform, delivery platform, promotion platform and other. Technology platform stack related to innovation technologies involves information systems platform, customer experience platform, data and analytics platform, IoT platform, ecosystems platform, trust platform, integration platform and other.

The digital business platform stack is intended to provide a higher level overview of the key capabilities necessary to assemble a digital business platform stack. With digital platform business models organised in BM portfolio, platform assets may be added or combined into new and different ways to support the digital platform strategy [LeHong et al., 2016; LeHong, 2019]. Delivering digital platform requires new capabilities to enable, support and evolve digital business [Burton, Basiliere, 2016].

A platform BM is a useful lens for understanding the company's platform underlying logic because it explains what value is provided, how this value is created and delivered and how profits can be generated therefrom. This concept helps to understand the capturing value from technological innovations and platforms [Chesbrough, Rosenbloom, 2002; Osterwalder, Pigneur, 2010; Osterwalder et al., 2014], the boundaries of a firm [Zott, Amit, Massa, 2010] and create a direct connection between business strategy and business processes [AlDebei, Avison, 2010]. Platform BM portfolio management is an important managerial function [Osterwalder, Pigneur, 2010; Hagiu, 2014]. It involves the ongoing monitoring of the activities that encompass the $\mathrm{BM}$ and of the incentives of all the stakeholders who participate in the BM. BM management thus could be viewed as a part of a firm's ordinary capabilities (in terms 


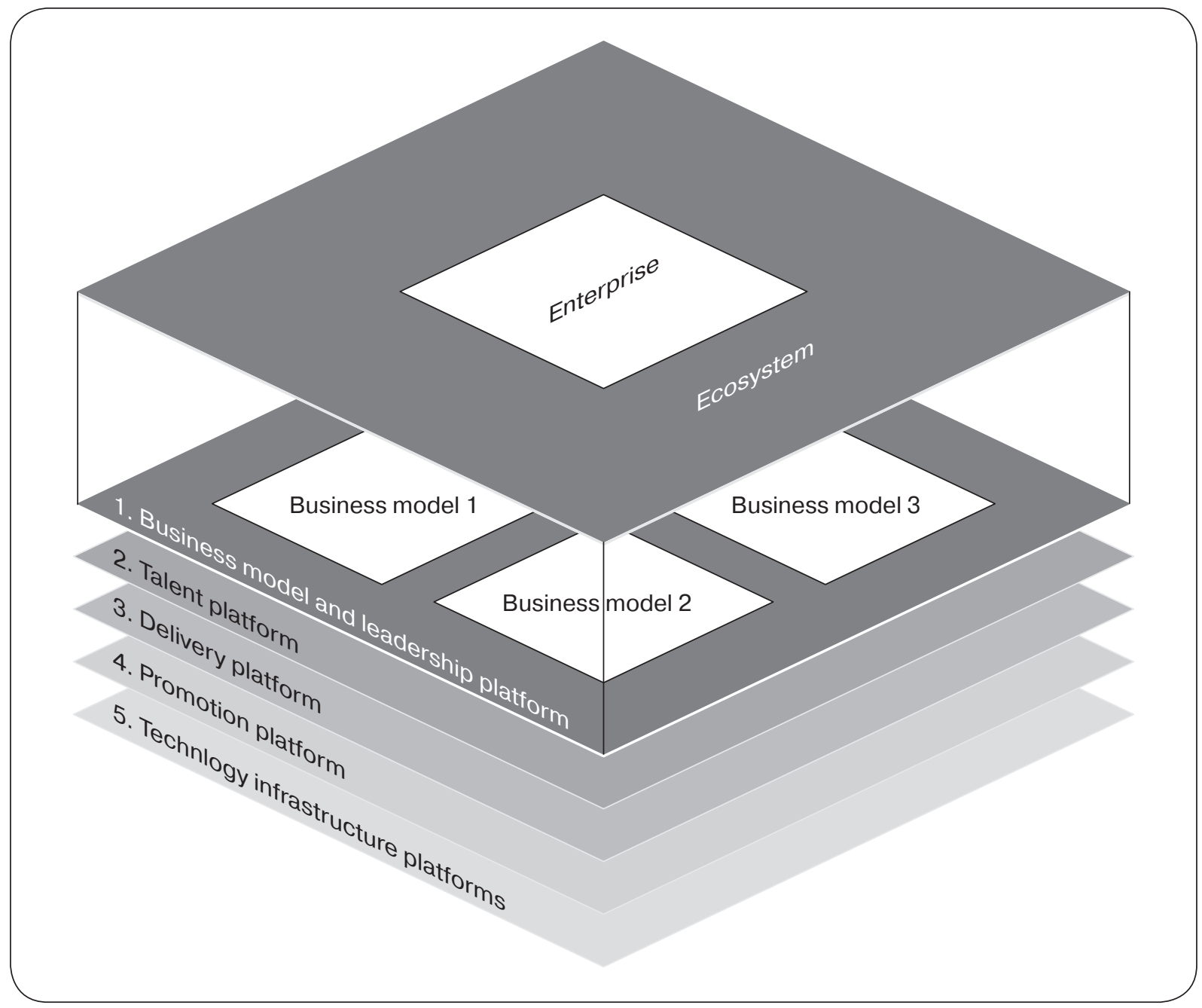

Fig. 4. Digital platform stack

B a s e d o n: [Yablonsky, 2018a; 2018b].

of the day-to-day performance of activities) and requires dynamic adaptation and transformation.

\section{Business platform stack}

Business platforms stack is to large extent related to platform capabilities [Teece, 2010]. The key roles of a BM and leadership platform are to collect dispersed sources of knowledge, to recombine the collected knowledge in order to empower innovation and management and to transfer it to new technological and organization contexts.
The goal of a talent platform is to facilitate knowledge exchange in BM and leadership environments and to offer affiliated economic agents the opportunity to access large intra ecosystem or ecosystem communities of economic agents with experiential, educational or professional knowledge in company's diverse geographical and disciplinary fields [Boudreau, 2010; Boudreau, Lacetera, Lakhani, 2011; Colombo et al., 2013; Colombo, Dell'Era, Frattini, 2015; Evans, Gawer, 2016]. A talent business platform creates value primarily by enabling direct interactions between two (or more) 
distinct types of affiliated talent consumers. The talent business platform is at the centre of the enterprise's relationship with talent. How can enterprise acquire and keep top talent in the age of digital business? In the relationships with top talent, enterprise can use marketers' tools and analyses. Seeing talent as a customer and employment by the talent platform as a brand promise fulfilled, can improve talent acquisition and retention. Persistent shortfalls in key talent areas show that enterprises have to act now to adapt their talent approaches to the digital world. A talent business platform serves the need of multiple customer segments - including enterprise executives and managers, HR professionals and recruiters and potential or current employees - to create and maintain engagement and evolving relationships between the enterprise and its contributors, internal and external [Hunter, Coleman, 2016]. Examples of sucessful external talent business platform with BM highly related with talent management are LinkedIn Talent, SmartRecruiters, TopCoder, Upwork etc. [Kaganer et al., 2013]. A key function of the talent platform is data capture and analysis related to talented individuals and talent pools - before, during and after their employment by the enterprise. The talent platform specifically supports an approach to talent that recognizes and leverages the "customer decision life cycle" of explore, evaluate and engage. Treating talent as a customer whose relationship with the enterprise includes a mix of exploration, evaluation and engagement over time is more realistic and fruitful for all involved than treating the acquisition of talent as a transaction.

A delivery business platform creates value primarily by enabling direct interactions between two (or more) distinct types of affiliated delivery consumers. Delivery business platforms create and maintain engagement and evolving relationships between the enterprise and its affiliated delivery consumers, internal and external. For example, Famous pizza chains like Domino's, Papa
John's and Pizza Hut have been investing heavily in food delivery business platform for years. These pizza giants have developed ordering systems for smartwatches, connected cars and even gaming consoles.

A promotion digital business platform creates value primarily by enabling direct promotion interactions between two (or more) distinct types of affiliated platform participants - consumers, producers and providers. It provides creating internally managed outbound messages and externally inbounded messages by platform participants themselves. A promotion platform influences platform participants - consumers, producers and providers - to submit multimedia messages, provide different types of activities and promote them on social media and platform ecosystems.

\section{Technology Platform Stack}

Technology platforms stack is related to innovation technologies. To manage the new digital BMs and business ecosystems, companies have to create a digital business platform to share critical assets. T. Coltman and M. Queiroz stated that a firm's strategy at the corporate level refers to the set of choices about how to compete across the different businesses that constitute the corporate profile [Coltman, Queiroz, 2015]. At this level, strategic decisions are made about how technological platforms can support levels of data sharing and business process standardization across business units.

Corporate level strategy is reflected in corporate technological platforms that include data, hardware, network, applications and management services that are shared by business units. Thus, a core function of technological platforms is to provide the foundation that allows business units to leverage common factors of production and to promote process synergies where the joint value creation is greater than the sum of the value created by individual businesses. Realizing these synergies requires continuous efforts of alignment to ensure integration 
of corporate strategy and corporate technological platforms capabilities.

Digital technology platforms are described through the lens of applications and business capability components they support (Fig.4). There are multiple layers to these technological platforms, which are necessary to effectively implement and integrate it in practice [LeHong et al., 2016]. All capabilities in the technology platforms' stack can be sourced from any combination of internal resources or external partners (insourcing, outsourcing, as-a-service and cloud sourcing).
The key concepts representing the components of technology platform stack are defined in the Table 2.

\section{FUTURE RESEARCH}

Platform companies are important for startups as well as incumbents. They are becoming an essential part of national systems of innovation. It was stated [Evans, 2016] that "the world's largest platform companies are not only earning more patents but are seed-

Definitions of core concepts on technology platforms

Table 2

\begin{tabular}{|c|c|}
\hline Concept & Definition \\
\hline 1 & 2 \\
\hline $\begin{array}{l}\text { The Enterprise } \\
\text { Technology } \\
\text { Architecture (ETA) }\end{array}$ & $\begin{array}{l}\text { ETA viewpoint defines reusable standards, guidelines, individual parts and } \\
\text { configurations that are technology-related (technical domains). ETA defines how } \\
\text { these should be reused to provide infrastructure services via technical domains }\end{array}$ \\
\hline $\begin{array}{l}\text { Information Systems } \\
\text { Platform (ISP) }\end{array}$ & $\begin{array}{l}\text { Supports the front and back office and operations, such as enterprise resource } \\
\text { planning and other core systems }\end{array}$ \\
\hline $\begin{array}{l}\text { Enterprise Resource } \\
\text { Planning (ERP) }\end{array}$ & $\begin{array}{l}\text { ERP is defined as the ability to deliver an integrated suite of business applica- } \\
\text { tions. ERP tools share a common process and data model, covering broad and } \\
\text { deep operational end-to-end processes, such as those found in finance, HR, } \\
\text { distribution, manufacturing, service and the supply chain. } \\
\text { ERP applications automate and support a range of administrative and operational } \\
\text { business processes across multiple industries, including line of business, custom- } \\
\text { er-facing, administrative and the asset management aspects of an enterprise. } \\
\text { ERP deployments are complex and expensive endeavors and some organizations } \\
\text { struggle to define the business benefits. } \\
\text { ERP looks for business benefits in four areas: a catalyst for business innovation, } \\
\text { a platform for business process efficiency, a vehicle for process standardization } \\
\text { and IT cost savings. Most enterprises focus on the last two areas, because they } \\
\text { are the easiest to quantify; however, the first two areas often have the most } \\
\text { significant impact on the enterprise }\end{array}$ \\
\hline $\begin{array}{l}\text { Customer Experience } \\
\text { Platform (CEP) }\end{array}$ & $\begin{array}{l}\text { Contains the main customerfacing counterparts, such as customer and citizen } \\
\text { portals, omni channel commerce and customer apps }\end{array}$ \\
\hline $\begin{array}{l}\text { Data and Analytics } \\
\text { Platform (DAP) }\end{array}$ & $\begin{array}{l}\text { Includes information management and analytical capabilities. Data management } \\
\text { programs and analytical applications fuel data-driven decision making and } \\
\text { algorithms automate discovery and action }\end{array}$ \\
\hline IoT Platform & $\begin{array}{l}\text { Enterprises are increasingly connecting a broad variety and number of IoT } \\
\text { endpoints to access data from and better manage physical assets that are relevant } \\
\text { to their business. IoT platform connects physical assets and smart machines } \\
\text { (smart things) for monitoring, optimization, control, analytics and monetization. } \\
\text { Capabilities include connectivity, analytics and integration to core and IoT } \\
\text { systems }\end{array}$ \\
\hline
\end{tabular}


Table 2 (end)

\begin{tabular}{c|l}
\hline $\mathbf{1}$ & \multicolumn{2}{c}{$\mathbf{2}$} \\
\hline Industrial IoT & Gartner defines the market for industrial IoT platforms as a set of integrated
\end{tabular}

Platforms $\quad$ software capabilities. These capabilities span efforts to improve asset management decision making, as well as operational visibility and control for plants, depots, infrastructure and equipment within asset-intensive industries. These efforts also occur within related operating environments of those industries.

The undustrial IoT platform may be consumed as a technology suite or as an open and general-purpose application platform, or both in combination. The platform

is engineered to support the requirements of safety, security and mission criticality associated with industrial assets and their operating environments. The industrial IoT platform software that resides on devices - such as, controllers, routers, access points, gateways and edge computing systems — is considered part of a distributed industrial IoT platform

Ecosystems Platform Supports the creation of and connection to, external ecosystems, marketplaces (EP) and communities. API management, control and security are its main elements

Application Programming Interface (API)

API is an interface that provides programmatic access to service functionality and data within an application or a database. It can be used as a building block for the development of new interactions with humans, other applications or smart devices. Companies use APIs to serve the needs of a digital transformation or an ecosystem and start a platform business model

Trust Platform (TP) $\quad$ A blockchain technology used to foster trust

Integration Platform Supports the integration of all above platforms that allows the maximum flexibil(IP)

Marketing Automation Platform (MAP) ity to support business transformation demands

MAP support lead management, scoring and nurturing activities across multiple marketing channels. The main goal of these systems is to convert contacts into scored, nurtured leads for sales teams to close. They assist with data cleansing by eliminating incomplete or redundant lead information and with lead augmentation by providing additional information about prospects. Lead process management and multi-channel orchestration and execution are the primary functions of marketing automation in a B2B or business-to-business-to-consumer (B2B2C) context. Digital ad operations platforms are advertising operations and management software for publishers and other sellers of digital advertising that support sales, pricing, optimization, yield management, analytics and delivery of advertising traffic and assets across multiple digital channels, including online, mobile, signage and new formats for digital TV

B as ed on: [Gartner glossary; Yablonsky, 2018b].

ing whole ecosystems of startups in cuttingedge areas of machine learning and artificial intelligence".

A. Hein and co-authors [Hein et al., 2019] summurize that particular challenge for digital platform strategy:

- the chicken-and-egg problem: the platform needs both the complementor and the consumer side to ensure a valid value proposition, but neither side is willing to join as long as the other side is not populated [Caillaud, Jullien, 2003];
- the multi-homing behavior of users by reducing the exclusivity and dominantfirm equilibria [Caillaud, Jullien, 2003; Koh, Fichman, 2014]. Digital platforms with a sufficient installed base - socalled platform leaders - can use their dominant position in the market to increase their market share even further [Gawer, Cusumano, 2014];

- platform envelopment to tap into new markets by subsidizing cloud-computing services or by using its information 
superiority to out-compete internal complementors [Zhu, 2018];

- intermediate perspective of value-creating mechanisms in the digital platform ecosystem considers the intersection between the internal digital platform and the platform owner, the external ecosystem and the autonomous complementors. A digital multilayered platform stack forms a competitive foundation upon which other firms can develop content, innovate with complementary technologies and create new services [Gawer, 2009; Yablonsky, 2018a; 2018b].

Recently P.Evans argued that "the political environment in Europe and the United States may point to a growth in nationalism, but the rapid growth of digital platforms, networks and data business models in fact represents the latest shift in the forces of globalization" [Evans, 2016]. Today it's difficult to disagree with opinion about a sig- nificant change in the platform strategy priorities [MIT, 2019, p.1]: “A decade ago, platform challenges seemed straightforward and the possibilities seemed endless. Strategists focused primarily on reducing transaction costs and on solving basic business problems. After that, they could drive scale and develop a revenue model. The mantra was: Get big fast! Now that platforms are sprawling and prolific businesses, a host of complex and far-reaching concerns are on the rise. Governance and regulation are topof-mind for market leaders... Increasingly, providers worry about fraud, hate speech, privacy, security and trolls."

Table 3 summarizes the current state and future research considerations developed in this article and similar prior studies [Parker, Van Alstyne, Choudary, 2016; McIntyre et al., 2017; De Reuver, Sørensen, Basole, 2018; Yablonsky, 2018b; Hein et al., 2019; Vial, 2019].

Table 3

Digital platforms research agenda

\begin{tabular}{|c|c|c|}
\hline Review area & Key elements & Future research agenda/questions for emerging markets \\
\hline 1 & 2 & 3 \\
\hline \multirow[t]{3}{*}{$\begin{array}{l}\text { Definition of } \\
\text { digital platform }\end{array}$} & $\begin{array}{l}\text { Economic definition } \\
\text { of MSP }\end{array}$ & $\begin{array}{l}\text { - Digital MSP business model industry patterns and portfolios } \\
\text { - Global and state regulations, polices and standards } \\
\text { - Digital consumer behavior regulations }\end{array}$ \\
\hline & $\begin{array}{l}\text { Functional/technical } \\
\text { definition }\end{array}$ & $\begin{array}{l}\text { - } \text { Platform stack } \\
\text { - } \text { - Private sector platforms } \\
\text { - Industry platforms } \\
\text { - Crowd in digital government/private platforms }\end{array}$ \\
\hline & $\begin{array}{l}\text { Transactional versus } \\
\text { nontransactional }\end{array}$ & - Testing for possible anticompetitive behavior \\
\hline $\begin{array}{l}\text { Platform } \\
\text { regulation and } \\
\text { policy concerns }\end{array}$ & $\begin{array}{l}\text { Data protection, data } \\
\text { privacy and data } \\
\text { portability }\end{array}$ & $\begin{array}{l}\text { - Regulatory, legal and institutional analysis in [emerging] } \\
\text { markets } \\
\text { - Data as essential facility } \\
\text { - Other }\end{array}$ \\
\hline $\begin{array}{l}\text { Platform } \\
\text { governance }\end{array}$ & Demand side policies & $\begin{array}{l}\text { - Cost-benefit analysis of demand stimulation policies and } \\
\text { interventions } \\
\text { - Other }\end{array}$ \\
\hline $\begin{array}{l}\text { Business } \\
\text { dynamics }\end{array}$ & Network effects & $\begin{array}{l}\text { - Winner-takes-some vs winner-takes all dynamics } \\
\text { - Interplatform competition and coopetition } \\
\text { - Nondiscriminatory access to the platform from third parties } \\
\text { - Dominance and use of data as an essential facility }\end{array}$ \\
\hline
\end{tabular}

РЖM 17 (4): 519-546 (2019) 
Table 3 (continued)

\begin{tabular}{|c|c|c|}
\hline 1 & 2 & 3 \\
\hline \multirow[t]{5}{*}{$\begin{array}{l}\text { Business } \\
\text { dynamics } \\
\text { (continued) }\end{array}$} & $\begin{array}{l}\text { Strength of network } \\
\text { effects }\end{array}$ & $\begin{array}{l}\text { - What drives the strength of network effects and how do } \\
\text { they manifest differently across industries, platforms and } \\
\text { sides (economic agents)? } \\
\text { - How can variation in network effects be conceptualized and } \\
\text { measured to predict differences in competitive outcomes } \\
\text { (e.g., single versus multiple platforms) across settings? } \\
\text { - How can firms effectively leverage an existing network across } \\
\text { platforms and over time? }\end{array}$ \\
\hline & $\begin{array}{l}\text { Drivers of indirect } \\
\text { network effects }\end{array}$ & $\begin{array}{l}\text { - What is the impact of exclusivity of complements on platform } \\
\text { - Wuccess? } \\
\text { - What aspects aside from total number of complements add } \\
\text { - How do complementor design moves such as porting influence } \\
\text { platform competitive outcomes? }\end{array}$ \\
\hline & Envelopment & $\begin{array}{l}\text { - Competition effect on third-party services and related goods } \\
\text { and services markets }\end{array}$ \\
\hline & Partnerships & $\begin{array}{l}\text { - Competition effect on third-party services and related goods } \\
\text { and services markets, through unilateral conduct or anticom- } \\
\text { petitive agreements } \\
\text { - Cross-platform data transfer/exchange and potential anticom- } \\
\text { petitive effect on third-party services }\end{array}$ \\
\hline & Platform quality & $\begin{array}{l}\text { - When and how much does quality matter in building and } \\
\text { leveraging an installed base? } \\
\text { - What are the critical dimensions of quality to users of compet- } \\
\text { ing platforms? } \\
\text { - How does the relative importance of quality dimensions impact } \\
\text { strategic choices such as entry timing in platform markets? }\end{array}$ \\
\hline \multirow[t]{2}{*}{ Enabling factors } & $\begin{array}{l}\text { Technological en- } \\
\text { ablers }\end{array}$ & $\begin{array}{l}\text { - IS platforms: Post-modern ERP platforms } \\
\text { - AI-driven Data and Analytics, IoT, Customer experience and } \\
\text { Ecosystem platforms } \\
\text { - Blockchain-based trust platforms } \\
\text { - Customer experience platforms and consumer equipment }\end{array}$ \\
\hline & Business enablers & $\begin{array}{l}\text { - BM and Leadership platform capabilities (Multi-hominess; col- } \\
\text { laborative consumption; managing in a multi-sided markets } \\
\text { and cyber-security risks; others) } \\
\text { - Talent platform capabilities } \\
\text { - Delivery platform capabilities } \\
\text { - Promotion platform capabilities (peer-to-peer feedback; } \\
\text { long-tail marketing; social-based personality assessments for } \\
\text { political messeging; others) }\end{array}$ \\
\hline \multirow[t]{2}{*}{$\begin{array}{l}\text { Technology } \\
\text { platform }\end{array}$} & $\begin{array}{l}\text { Nature and actions } \\
\text { of complementors }\end{array}$ & $\begin{array}{l}\text { - What is the role of complementor attributes in explaining their } \\
\text { decisions to link to platforms? } \\
\text { - How does complementor age, size and prior experience influ- } \\
\text { ence their choice of platform? } \\
\text { - When does prior experience with a platform enhance or con- } \\
\text { strain complementor adaptation? }\end{array}$ \\
\hline & $\begin{array}{l}\text { Leveraging comple- } \\
\text { mentor dynamics for } \\
\text { competitive advan- } \\
\text { tage }\end{array}$ & $\begin{array}{l}\text { - What are the optimal platform design strategies, such as degree } \\
\text { of openness, in building an ecosystem of complementors? } \\
\text { - How can platform firms extend their reach to newer markets } \\
\text { by leveraging their existing architectures and complementor } \\
\text { networks? }\end{array}$ \\
\hline
\end{tabular}


Table 3 (end)

\begin{tabular}{|c|c|c|}
\hline 1 & 2 & 3 \\
\hline $\begin{array}{l}\text { Technology } \\
\text { platform } \\
\text { (continued) }\end{array}$ & $\begin{array}{l}\text { Technical properties } \\
\text { and value creation }\end{array}$ & $\begin{array}{l}\text { - When, why and how is the stable core altered to introduce new } \\
\text { affordances? } \\
\text { - How does the platform owner balance the standardization and } \\
\text { interpretative flexibility of boundary objects? }\end{array}$ \\
\hline \multirow[t]{3}{*}{$\begin{array}{l}\text { Digital platform } \\
\text { ecosystem }\end{array}$} & $\begin{array}{l}\text { Complementor } \\
\text { interaction with the } \\
\text { ecosystem }\end{array}$ & $\begin{array}{l}\text { - How do different types of complementors interact with } \\
\text { the digital platform to increase generativity? } \\
\text { - How can complementors in ecosystems influence the strategic } \\
\text { decisions of owners of digital platforms? }\end{array}$ \\
\hline & $\begin{array}{l}\text { Make-or-join decision } \\
\text { in digital platform } \\
\text { ecosystems }\end{array}$ & $\begin{array}{l}\text { - When and how should firms establish a new digital platform } \\
\text { ecosystem? } \\
\text { - When and how should firms join an existing digital platform } \\
\text { ecosystem? } \\
\text { - Which technical, economic and ecosystem capabilities do plat- } \\
\text { form owners need to build a digital platform ecosystem? } \\
\text { - How do we motivate complementors to join, grow, stay and } \\
\text { engage in the digital platform ecosystem? }\end{array}$ \\
\hline & Value capture & $\begin{array}{l}\text { - What is the ideal degree of value capture in different com- } \\
\text { petitive situations and lifecycle stages of a digital platform? } \\
\text { - How is value shared in a digital platform ecosystem owned by } \\
\text { a consortium or a peer-to-peer community? } \\
\text { - How the platform owner/provider/user can influence the value- } \\
\text { creating mechanisms in the digital platform ecosystem? }\end{array}$ \\
\hline \multirow[t]{2}{*}{$\begin{array}{l}\text { Business\& } \\
\text { Technology } \\
\text { platforms }\end{array}$} & $\begin{array}{l}\text { Business and } \\
\text { Technology platforms } \\
\text { intersection }\end{array}$ & $\begin{array}{l}\text { - How to manage the growing intersection of physical and dig- } \\
\text { ital worlds in organisation? }\end{array}$ \\
\hline & $\begin{array}{l}\text { Platform enterprise } \\
\text { technology architec- } \\
\text { ture (PETA) }\end{array}$ & $\begin{array}{l}\text { - How business platforms have to be supported by technology } \\
\text { platforms in seven overlapping areas of platform stack? } \\
\text { - What are basic challenges of assessing, aligning and organiz- } \\
\text { ing business objectives with digital platform technical require- } \\
\text { ments and strategies? } \\
\text { - At what point do additional investments in platform archi- } \\
\text { tecture and governance no longer pay off in terms of value } \\
\text { capture? } \\
\text { - PETA versus ordinary enterprise technology architecture } \\
\text { frameworks with the goal of addressing the basic challenge } \\
\text { of assessing, aligning and organizing business objectives with } \\
\text { technical requirements and strategies }\end{array}$ \\
\hline
\end{tabular}

\section{CONCLUSION}

Platforms enable new products/services by reusing platform components. They have lower fixed costs and enable service providers to market in a shorter period of time. Market platform intermediaries usually reduce search and transactions costs for in- teractions among two or more distinct groups of customers (e.g. suppliers and consumers for 7-Eleven; sellers and buyers for eBay). The MSP literature is now regularly cited by competition authorities and courts [Evans, Schmalensee, 2018]. These businesses pose novel problems for competition policy [Evans, 2003; Evans, Schmalen- 
see, 2015]. However, M.Cusumano, A. Gawer and D. Yoffie affirm that platform businesses can stand the test of time and win their share of battles with both digital and conventional competitors [Cusumano, Gawer, Yoffie, 2019]. Authors argue that "platforms can produce the fastest growing and highest profits companies in the world; and they can also become a formula for losing a fortune while threaten democracy and political stability" [Cusumano, Gawer, Yoffie, 2019]. They assert that "the world's most valuable companies are all platforms, in part because platforms have network effects, with the potential for a winner-takeall or winner-take-most outcome". However, "failure is more likely than winner-take-all: mispricing, mistrust, mistiming and hubris lead to hundreds of failures compared to relatively few successes" [Cusumano, Gawer, Yoffie, 2019]. To understand why and how platforms fail, D. Yoffie and co-authors identify 209 failures of American platforms over the last twenty years that competed with the 43 successful platforms [Yoffie et al., 2019]. The average life of the failed platforms was only 4.9 years, many platforms collapsed within $2-3$ years because they did not have enough users or funding. Scholars argue that standalone firms tended to have shorter lives than those that were acquired or launched as part of a larger firm or consortium of firms, who were capable of fighting longer (averaged 7.4 years). Overall, factors of digital platforms failures involve mispricing on one side of the market, inability to develop trust with users and partners, late entering or early dismissal of the competition [Cusumano, Gawer, Yoffie, 2019; Yoffie et al., 2019].

In reply to the challenges of the digital economy and high dynamics of platform business transformation, enterprises need the following:

- methodology for systematic digital platform business modelling based on a language both business and technology experts equally understand. An example of such theoretically and practically im- proved multi-methodology for platform strategic and BM research is proposed in [Yablonsky, 2018a]. EA is most commonly associated with IT. In [Yablonsky, 2018a], a simplified, top-down approach of decision making of EA design is described in the context of business platform architecture. It focuses the on technology side with the objective of providing a better alignment between business and IT. Our research focused on the digital platform stack (necessary platform components such as technology, leadership, talent and skills, delivery, trust, marketing, ecosystem and BMs) required to support the capabilities of digital business innovations;

- new capabilities to use the potential relationship of artificial intelligence, big data and advanced analytics with digital business platforms. In doing so, organization has to develop technology-enabled innovation value chain to be used with a focus on data-driven human-machine relationships and apply artificial intelligence at different levels of data driven automation maturity [Yablonsky, 2019]. In the current digital age, when intangible assets are becoming more crucial for a firm's performance, new big-datadriven value dimensions can support business leaders and management teams to provide more effective measurement and management of their intellectual and information capital assets;

- next-generation operating models based on intelligent process automation to be more agile, quicker to react and more effective. Platform busineses have to deliver great customer experiences, take advantage of new technologies to cut costs, improve quality and transparency and build value;

- transformation of platform organization culture. Success in establishing the new execution model will depend on how well it is aligned with the organization culture and how successfully emploees are able to adapt to agile practices. 
PLATFORM BMP

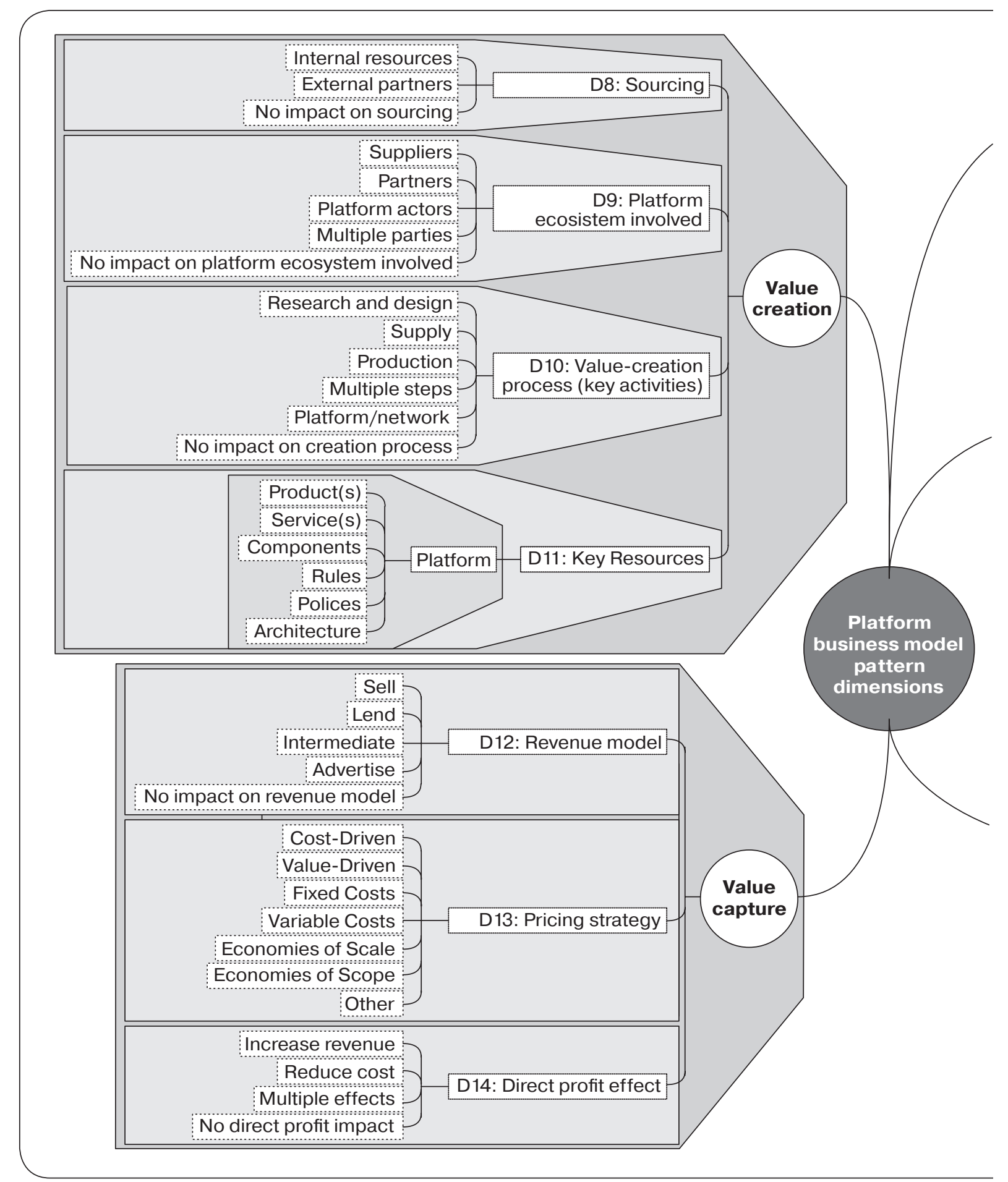

S o u r c e: [Yablonsky, 2018a; 2018b]. 


\section{DIMENSIONS}

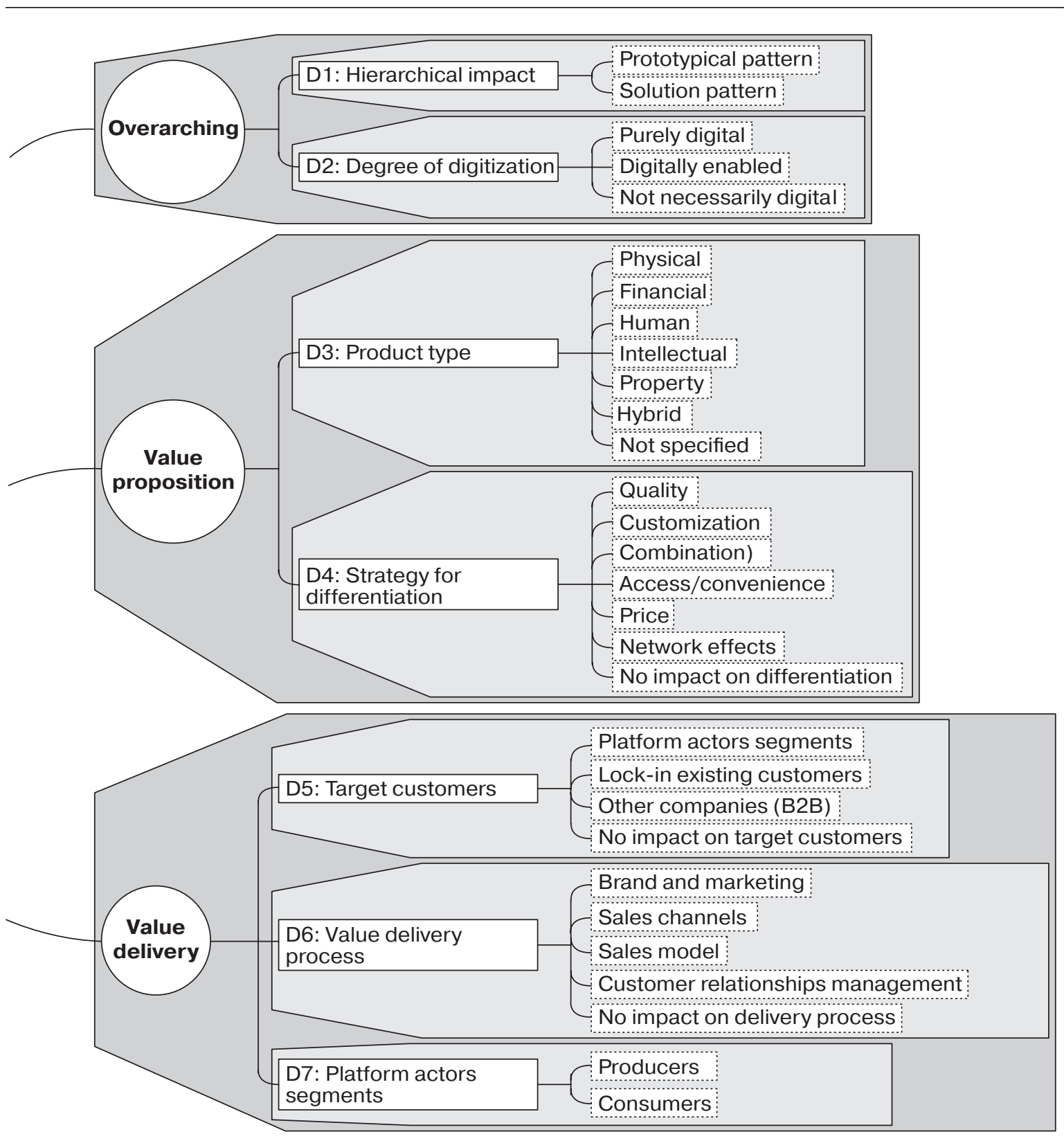




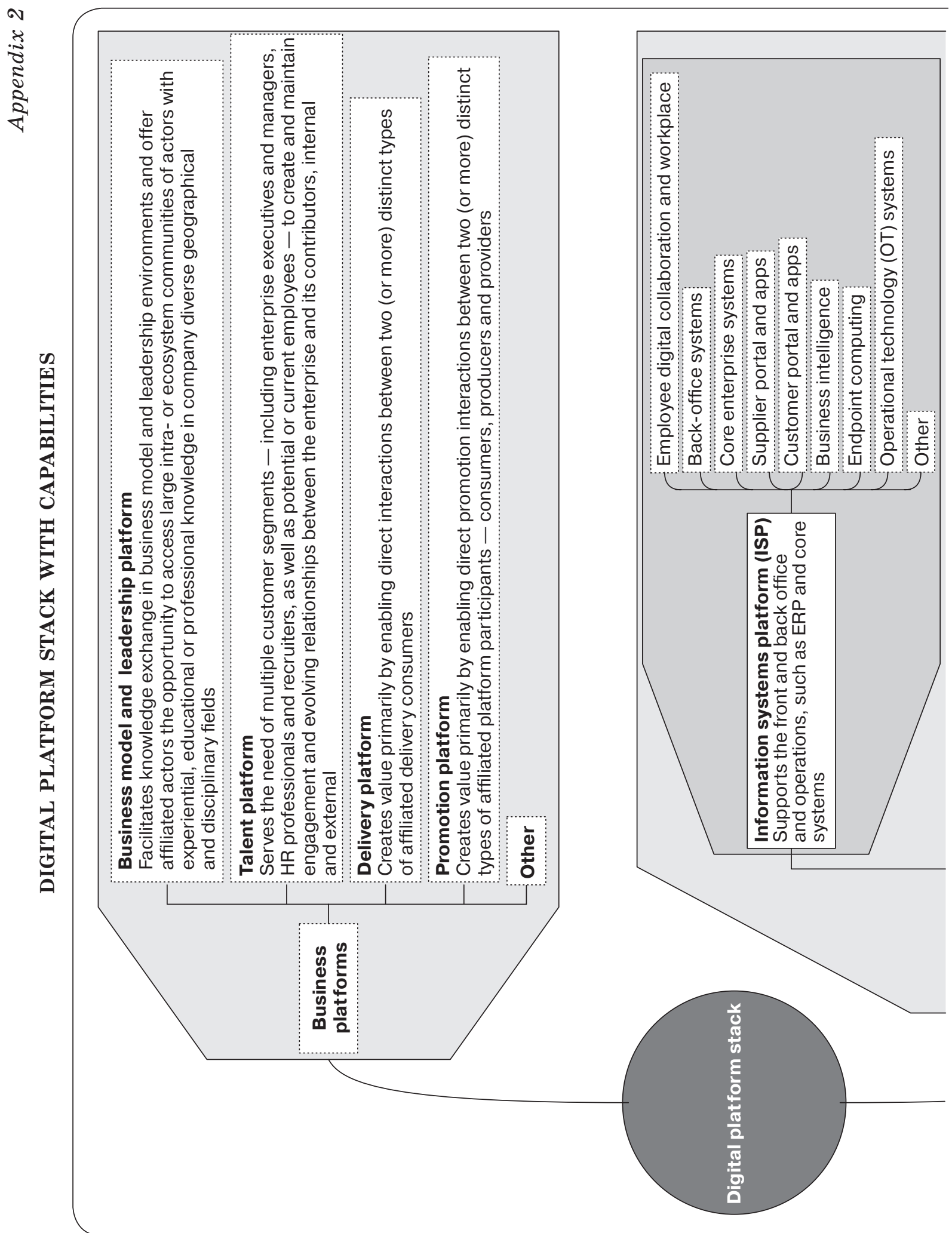




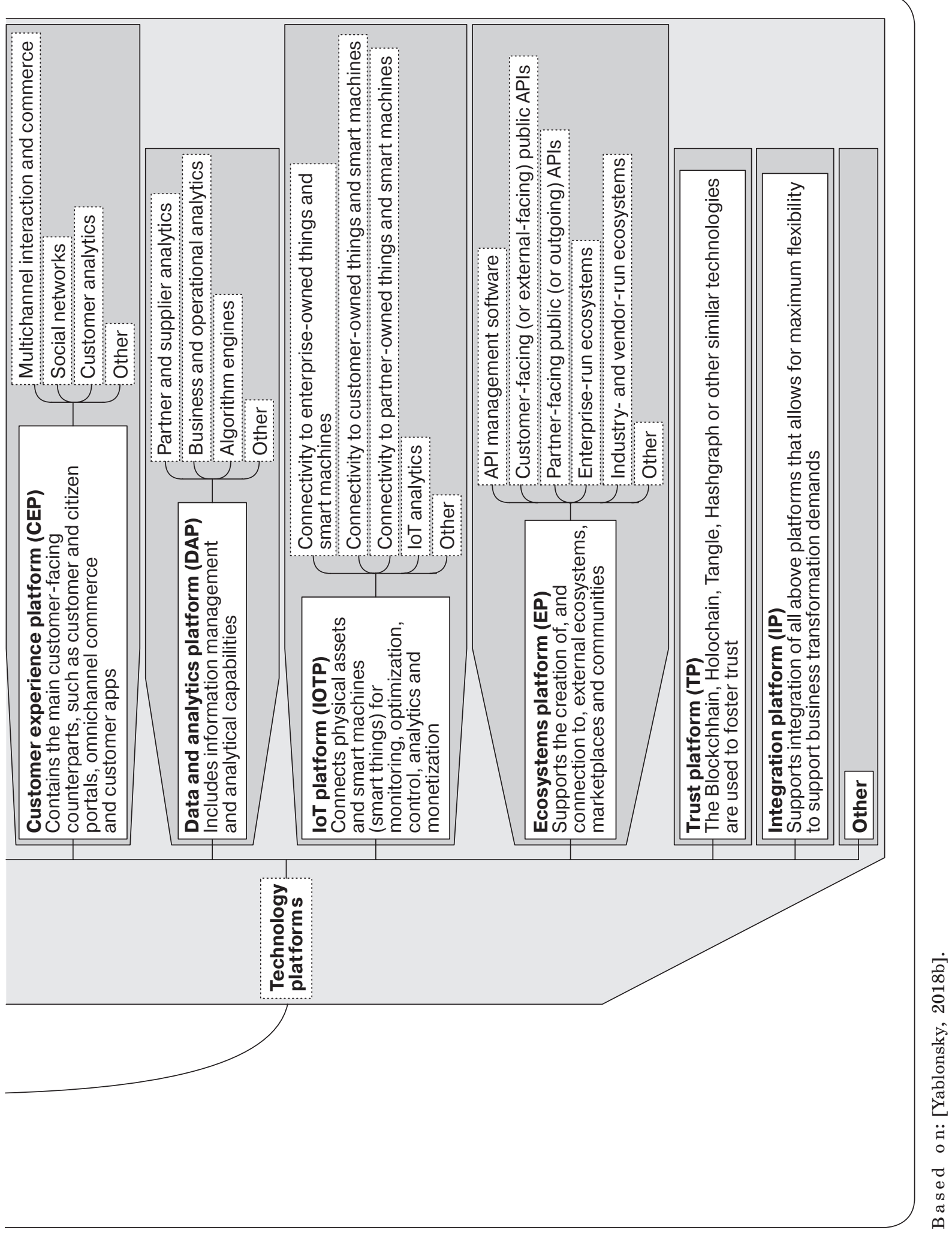

PЖM 17 (4): 519-546 (2019) 


\section{REFERENCE}

Abdelkafi N., Raasch C., Roth A., Srinivasan R. 2019. Multi-sided platforms. Electronic Markets 29 (4): 553-728.

Al-Debei M.M., Avison D. 2010. Developing a unified framework of the business model concept. European Journal of Information Systems 19 (3): 359-376.

Aversa P., Haefliger S., Reza D. G. 2017. Building a winning business model portfolio. MIT Sloan Management Review $\mathbf{5 8}$ (4): $49-54$.

Bente S., Bombosch U., Shailendra L. 2012. Collaborative Enterprise Architecture: Enriching EA with Lean, Agile and Enterprise 2.0 Practices. Morgan Kaufmann Publishers: Waltham, MA.

Blaschke M., Cigaina M., Riss U., Shoshan I. 2017a. Designing business models for the digital economy. In: Shaping the Digital Enterprise. Trends and Use Cases in Digital Innovation and Transformation. G. Oswald, M. Kleinemeier (eds). Springer International Publishing: Switzerland.

Blaschke M., Haki M. K., Riss U., Aier S. 2017b. Design principles for business-model-based management methods. A servicedominant logic perspective. In: A. Maedche, J.vom Brocke, A. Hevner (eds). Designing the Digital Transformation: 12th International Conference. DESRIST 2017; 179198. Springer International Publishing: Karlsruhe, Germany.

Blosch M., Burton B. 2016. Architecting platform ecosystems is key to integrate people, business and things. Gartner. [Electronic resource]. https://www.gartner.com/doc/ 3196533? $\mathrm{ref}=$ SiteSearch\&sthkw $=$ Platform $\%$ 20Business \% 20Model\%20 Orchestration \& $\mathrm{fnl}=$ search\&srcId $=1-3478922254$ (accessed: 18.12.2019).

Boley H., Chang E. 2007. Digital ecosystems: Principles and semantics. In: IEEE International Digital Ecosystems and Technologies Conference; 398-403. IEEE: Cairns, Australia.

Boudreau K. 2010. Open platform strategies and innovation: Granting access vs. devolving control. Management Science 56 (10): 1849-1872.
Boudreau K.J., Lacetera N., Lakhani K.R. 2011. Incentives and problem uncertainty in innovation contests: An empirical analysis. Management Science 57 (5): 843-863.

Burton B., Basiliere P. 2016. Architect digital platforms to deliver business value and outcomes. Gartner. [Electronic resource]. https://www.gartner.com/doc/3518917? ref $=$ SiteS earch\&sthkw $=$ PLATFORM $\% 20$ STACK\&fnl $=$ search\&srcId $=1-3478922254$ (accessed: 18.12.2019).

Caillaud B., Jullien B. 2003. Chicken \& Egg: Competition among Intermediation Service Providers. The RAND Journal of Economics 34 (2): 309-328.

Chesbrough H., Rosenbloom R. 2002. The role of the business model in capturing value from innovation: Evidence from $\mathrm{Xe}$ rox Corporation's technology spin-off companies. Industrial and Corporate Change 11 (3): 529-555.

Como E., Mathis A., Tognetti M., Rapisardi A. 2016. Cooperative platforms in European landscape: an explaratory study. ISIRC Conference, Glasgow.

Constantinides P., Henfridsson O., Parker G. G. 2018. Platforms and infrastructures in the digital age. Information Systems Research 29 (2): 381-400.

Colombo G., Buganza T., Klanner I.-M., Roiser S. 2013. Crowdsourcing intermediaries and problem typologies: An explorative study. International Journal of Innovation Management 17 (2): 1-24.

Colombo G., Dell'Era C., Frattini F. 2015. Exploring the contribution of innovation intermediaries to the new product development (NPD) process: A typology and an empirical study. $R$ \& $D$ Management 45 (2): 126-146.

Coltman T., Queiroz M. 2015. Information technology and strategy. In: M. Augier, D. J. Teece (eds). The Palgrave Encyclopedia of Strategic Management. Palgrave Macmillan: London. [Electronic resource]. http://www.palgraveconnect.com/esm/doifinder/10.1057/ (accessed: 08.12.2019).

Cusumano M.A., Gawer A., Yoffie D. B. 2019. The Business of Platforms: Strategy in the 
Age of Digital Competition, Innovation, and Power. Harper Business: N.Y.; 309 p.

David-West O., Evans P.C. 2016. The rise of African platforms: A regional survey. The Emerging Platform Economy Series No 2. The Centre for Global Enterprise (CGE). [Electronic resource]. https://www.thecge.net/?s= The + rise + of + African + platforms $\% 3 \mathrm{~A}+\mathrm{A}+$ regional+survey (accessed: 08.12.2019).

De Reuver M., Sørensen C., Basole R.C. 2018. The digital platform: A research agenda. Jurnal of Information Technology 33 (2): 124-135.

Eaton B., Elaluf-Calderwood S., Sorensen C., Yoo Y. 2015. Distributed tuning of boundary resources: The case of Apple's iOS service system. MIS Quarterly: Management Information Systems 39 (1): 217-243.

Einav L., Kuchler T., Levin J. D., Sundaresan N. 2011. Learning from Seller Experiments in Online Markets. Mimeo.

Evans D.S. 2003. Some empirical aspects of multi-sided platform industries. Review of Network Economics 2 (3): 191-209.

Evans P.C. 2016. CGE highlights globalization of platform business models at 2016 MIT Platform Strategy Summit. The Center of Global Enterprise. [Electronic resource]. https://www.thecge.net/cge-highlights-globalization-of-platform-businessmodels-at-2016-mit-platform-strategy-summit/ (accessed: 8.12.2019).

Evans P.C., Gawer A. 2016. The rise of the platform enterprise: A global survey. Center for Global Enterprise. [Electronic resource]. http://www.thecge.net/wp-content/ uploads/2016/01/PDF-WEBPlatform-Survey_01_12.pdf (accessed: 08.12.2019).

Evans D.S., Hagiu A., Schmalensee R. 2006. Invisible Engines: How Software Platforms Drive Innovation and Transform Industries. 1st ed. MIT Press: Cambridge, MA.

Evans D.S., Schmalensee R. 2016. Matchmakers: The New Economics of Multisided Platforms, Harvard Business Review Press, $272 \mathrm{p}$.

Evans D.S., Schmalensee R. 2018. Multi-sided platforms. In: The New Palgrave Dictionary of Economics; 9200-9208. Palgrave Macmillan: London.
Flood R.L., Jackson M.C. 1991. Creative Problem Solving: Total Systems Intervention. Wiley: Hoboken, NJ.

Gartner Glossary. Gartner. [Electronic resource]. https://www.gartner.com/en/glossary (accessed: 18.12.2019).

Gassmann O., Frankenberger K., Csik M. 2014. Revolutionizing the business model. In: O. Gassmann, F. Schweitzer (eds). Management of the Fuzzy Front end of Innovation; 89-97. Springer International Publishing: Switzerland.

Gawer A. 2009. Platform dynamics and strategies: From products to services In: A. Gawer (ed.) Platforms, Markets and Innovation. Edward Elgar Publishing: Cheltenham.

Gawer A. 2014. Bridging differing perspectives on technological platforms: Toward an integrative framework. Research Policy 43 (7): 1239-1249.

Gawer A., Cusumano M.A. 2002. Platform Leadership: How Intel, Microsoft and CISCO Drive Industry Innovation. Harvard Business School Press: Boston, MA.

Gawer A., Cusumano M. A. 2008. How companies become platform leaders. MIT Sloan Management Review 49 (2): 28-35.

Gawer A., Cusumano M. 2014. Industry platforms and ecosystem innovation. Journal of product innovation management 31 (3): 417-433.

Gentzkow M., Shapiro J. 2011. Ideological segregation online and offline. Quarterly Journal of Economics 126 (4): 1799-1839.

Goldfarb A., Tucker C. E. 2011. Privacy regulation and online advertising. Management Science 57 (1): 57-71.

Günzel F., Holm A. B. 2013. One size does not fit all - Understanding the front-end and back-end of business model innovation. International Journal of Innovation Management 17 (1): 1-34.

Jacobides M. G., Cennamo C., Gawer A. 2018. Towards a theory of ecosystems. Strategic Management Journal 39 (8): 2255-2276.

Judah S. 2016. Disruption and the Digital Value of Business - the Rise of Digital Economics. Gartner. [Electronic resource]. https://www.gartner.com/en/documents/ $3456117 /$ disruption-and-the-digital-value-ofbusiness-the-rise-of (accessed: 18.12.2019). 
Hagiu A. 2014. Strategic decisions for multisided platforms. MIT Sloan Management Review 55 (2): 92-93.

Hagiu A., Wright J. 2015. Multi-Sided Platforms. Working Paper 15-037.

Hein A., Schreieck M., Riasanow T., Setzke T., Wiesche M., Böhm M., Krcmar H. 2019. Digital platform ecosystems. Electronic Markets (1): 1-12.

Hess T., Matt C., Benlian A., Wiesboeck F. 2016. Options for formulating a digital transformation strategy. MIS Quarterly Executive 15 (2): 123-139.

Hunter R., Coleman M. 2016. Competing for top talent: Build the talent platform. Gartner Research, ID G00308714.

IDC 2017. Third-Platform Concept. [Electronic resource]. http://www.idc.com/promo/ thirdplatform/ (accessed: 18.12.2019).

Kaganer E., Carmel E., Hirschheim R., Olsen T. 2013. Managing the Human Cloud. MIT Sloan Management Review 54 (2): 23-32.

Koh T., Fichman M. 2014. Multi-homing users' preferences for two-sided exchange networks. MIS Quarterly 38 (4): 977-996.

Kornberger M., Pflueger D., Mouritsen J. 2017. Evaluative infrastructures: Accounting for platform organization. Accounting, Organizations and Society 60: 79-95.

LeHong H. 2019. Digital business overview: Major frameworks in one report. Gartner. [Electronic resource]. https://www.gartner. com/doc/3948227 (accessed: 24.12.2019).

LeHong H., Howard C., Gaughan D., Logan D. 2016. Building a digital business technology platform. Gartner. [Electronic resource]. https://www.gartner.com/binaries/content/assets/events/keywords/ symposium/esc28/esc28_digitalbusiness.pdf (accessed: 24.12.2019).

Leiblein M. 2015. Platform innovation. In: M.Augier, D. Teece (eds). The Palgrave Encyclopedia of Strategic Management. [Electronic resource]. http://www.palgraveconnect. com/esm/doifinder/10.1057/97811372 94678.0794 (accessed: 08.12.2019).

Levin J. 2012. The economics of Internet markets. In: D. Acemoglu, M. Arellano, E. Dekel (eds). Advances in Economics and Econometrics: Tenth World Congress; Vol.1. New York: Cambridge University Press: N.Y.
McIntyre D. P., Srinivasan A. 2017. Networks, platforms, and strategy: Emerging views and next steps. Strategic Management Journal 38 (1): 141-160.

Menon K., Kärkkäinen H., Wuest T., Gupta J.P. 2018. Industrial Internet platforms: A conceptual evaluation from a product lifecycle management perspective. Proceedings of the Institution of Mechanical Engineers, Part B: Journal of Engineering Manufacture 233 (5): 1390-1401.

MIT. 2019. MIT Platform Strategy Summit.

Moore J.F. 1996. The death of competition: Leadership and strategy in the age of business ecosystems. HarperCollins: N.Y.

Moore J.C., Rao H.R., Whinston A., Nam K., Raghu T.S. 1997. Information acquisition policies for resource allocation among multiple agents. Information Systems Research 8 (2): 151-170.

Moyer K. 2016. Industry visions for digital business set the terms of competition. Gartner Research, ID: G00307722.

Nickerson R., Upkar V., Muntermann J. 2013. A method for taxonomy development and its application in information systems. European Journal of Information Systems 22 (3): 336-359.

Ojala A., Lyytinen K. 2018. Competition logics during digital platform evolution. In: Proceedings of the 51st Hawaii International Conference on System Sciences.

Osterwalder A. 2004. The Business Model Ontology - A proposition in a Design Science Approach (Ph. D. Thesis). University of Lausanne, Ecole des Hautes Etudes Commerciales HEC.

Osterwalder A., Pigneur I. 2010. Business Model Generation: A Handbook for Visionaries, Game Changers, and Challengers. John Wiley \& Sons: Hoboken, NJ.

Osterwalder A., Pigneur Y., Bernarda G., Smith A. 2014. Value Proposition Design: How to Create Products and Services Customers Want. John Wiley \& Sons: Hoboken, NJ.

Oswald G., Kleinemeier M. (eds). 2017. Shaping the Digital Enterprise. Trends and Use Cases in Digital Innovation and Transformation. Springer International Publishing: Switzerland. 
Parker G., Van Alstyne M. 2005. Two-sided network effects: A theory of information product design. Management Science $\mathbf{5 1}$ (10): 1494-1504.

Parker G., Van Alstyne M. 2014. Platform Strategy. In: M. Augier, D. Teece (eds). The Palgrave Encyclopedia of Strategic Management. Palgrave Macmillan: London.

Parker G.G., Van Alstyne M. W., Choudary S.P. 2016. Platform Revolution: How Networked Markets are Transforming the Economy, and How to Make Them Work for You. W. W. Norton \& Company: N.Y.

Parker G., Van Alstyne M., Jiang X. 2017. Platform ecosystems: How developers invert the firm. MIS Quarterly 41 (1): 255-266.

Remane G., Hanelt A., Tesch J., Kolbe L. M. 2017. The business model pattern database - a tool for systematic business model innovation. International Journal of Innovation Management 21 (1).

Rochet J.-C., Tirole J. 2003. Platform competition in two-sided markets. Journal of the European Economic Association 1 (4): 990-1029.

Rochet J.-C., Tirole J. 2004. Two-sided markets: Where we stand. RAND Journal of Economics 33 (4).

Rochet J.-C., Tirole J. 2006. Two-sided markets: A progress report. RAND Journal of Economics 37 (3): 645-667.

Taube A. 2014. The 20 Most Valuable Brands In The World. [Electronic resource]. http:// www.businessinsider.com/the-20-most-valu-able-brands-in-the-world-2014-5?op=1 \#ixzz3KMHUTYmY (accessed: 08.12.2019).

Teece D. 2012. Next generation competition: New concepts for understanding how innovation shapes policy in the digital economy. The Journal of Law, Economics \& Policy 9 (1): 97-118.

Teece D. 2010. Business models, business strategy and innovation. Long Range Planning 43 (2-3): 172-194.

Tiwana A. 2014. Platform Ecosystems. Aligning Architecture, Governance, and Strategy. Morgan Kaufmann: Waltham, MA.

Tiwana A., Konsynski B., Bush A.A. 2010. Platform evolution: Coevolution of platform architecture, governance, and environmental dynamics. Information Systems Research 21 (4): 675-687.
Thom N. 2010. Measuring the value contribution of foresight. In: 3rd ISPIM Innovation Symposium: Quebec City. Canada.

Thomas L. D. W., Autio E., Gann D. M. 2014. Architectural leverage: Putting platforms in context. The Academy of Management Perspectives 28 (2): 198-219.

Van Alstyne M.W., Parker G.G., Choudary S.P. 2016. 6 Reasons Platforms Fail. Harvard Business Review Digital Article. [Electronic resource]. https://hbr.org/2016/03/6-reasons-platforms-fail (accessed: 16.12.2019).

Verhoef P.C., Broekhuizen T., Bart Y., Bhattacharya A., Qi Dong J., Fabian N., Haenlein M. 2019. Digital transformation: A multidisciplinary reflection and research agenda. Journal of Business Research. In press.

Vial G. 2019. Understanding digital transformation: A review and a research agenda. The Journal of Strategic Information Systems 28 (2): 118-144.

White A. 2018. Online platforms, economics of. In: The New Palgrave Dictionary of Economics; 9790-9797. Palgrave Macmillan: London.

Yablonsky S. 2013. Multisided Platforms and Markets: Basic Approaches, Concepts and Practices, The Russian Management Journal 11 (4): 57-78.

Yablonsky S. 2016a. Multi-sided search platforms: global and local. The International Journal of Technology Marketing 11 (3): 319-340.

Yablonsky S. 2016b. Intermediaries in e-commerce. In: I. Lee (ed.). Encyclopedia of $E$ Commerce Development, Implementation, and Management; 48-73. IGI Global: Hershey, PA.

Yablonsky S. 2018a. A Multidimensional framework for digital platform innovation and management: From business to technological platforms. Systems Research and Behavioral Science 35 (4): 485-501.

Yablonsky S. 2018b. Multi-Sided Platforms (MSPs) and Sharing Strategies in the Digital Economy: Emerging Research and Opportunities. Advances in E-Business Research (AEBR) Book Series, IGI Global: Hershey, PA.

Yablonsky S. 2019. Multidimensional DataDriven Artificial Intelligence Innovation. 
Technology Innovation Management Review (TIM Review) 9 (12). [Electronic resource]. https://timreview.ca/article/1288 (accessed: 27.12.2019).

Yoffie D., Gawer A., Cusumano M. 2019. A study of more than 250 platforms a reveal why most fail. Harvard Business Review, $2019 / 5 / 29$.

Zhang M., Zhu F. 2011. Group size and incentives to contribute: A natural experiment at Chinese Wikipedia. American Economic Review 101: 1601-1615.
Zhu F. 2018. Friends or foes? Examining platform owners' entry into complementors' spaces. Journal of Economics \& Management Strategy 28 (10): 23-28.

Zott C., Amit R., Massa L. 2010. The Business Model: Theoretical Roots, Recent Developments, and Future Research. Working Paper WP-862. IESE Business School University of Navarra: Barcelona, Spain. [Electronic resource]. http://www.iese.edu/ research/pdfs/DI-0862-E. pdf (accessed: 18.12.2019).

Initial Submission: September 30, 2019

Final Version Accepted: December 27, 2019

\title{
Многосторонние платформы: современное состояние и будущие исследования
}

\author{
С.А.Яблонский \\ Институт «Высшая школа менеджмента» Санкт-Петербургского государственного \\ университета, Россия
}

В цифровую эпоху платформенные компании Facebook, Amazon, Uber, Airbnb и другие существенно изменили традиционные способы ведения бизнеса. Многосторонние платформы представляют относительно новое явление цифровой экономики, требующее всестороннего научного и практического анализа. В статье дается обзор исследований по проблематике цифровых многосторонних платформ. Рассматриваются основные компоненты и характеристики цифровых платформ, а также преимущества, недостатки, возможности и угрозы, связанные с их деятельностью. Обсуждаются последние работы в области анализа и создания стратегий, бизнес-моделей и архитектур платформ и предлагается программа дальнейших исследований.

Ключевые слова: бизнес-платформа, технологическая платформа, многосторонняя платформа, бизнес-модель платформы, стек платформы.

JEL: O31, O32.

For citation: Yablonsky A.S. 2019. Multi-sided platforms: Current state and future research. Russian Management Journal 17 (4): 519-546.

\author{
Статья поступила в редакцию \\ 30 сентября 2019 г. \\ Принята к публикации \\ 27 декабря 2019 г.
}

